\title{
PEMBELAJARAN SASTRA POPULER BERBASIS WATTPAD SEBAGAI UPAYA PENINGKATAN KEMAMPUAN LITERASI BACA TULIS
}

\author{
Wattpad Based Popular Literature Learning as an Effort to Improve Literacy \\ Tristanti Apriyani \\ Program Studi Sastra Indonesia \\ Universitas Ahmad Dahlan \\ e-mail: tristantiapriyani@gmail.com
}

(Naskah Diterima tanggal 17 Januari 2020-Direvisi tanggal 24 Februari 2020-Disetujui tanggal 24 Februari 2020)

\begin{abstract}
Abstrak
Kemampuan literasi mahasiswa Prodi Sastra Indonesia Universitas Ahmad Dahlan masih kurang mendapatkan perhatian dan penanganan. Hal ini mengakibatkan rendahnya kemampuan mahasiswa dalam kemampuan literasi baca tulis. Sementara kemampuan literasi dapat membantu mahasiswa untuk mengembangkan berpikir kritis, divergent thinking, dan positive thinking dalam menyelesaikan masalah. Sebagai insan cendekia, calon ilmuwan dan agen perubahan, mahasiswa dituntut untuk menguasai kemampuan literasi serta berfikir kritis dalam menghadapi persaingan ketat abad ke-21. Kemampuan literasi yang dimaksud adalah keberaksaraan atau literasi dalam arti luas yaitu sadar akan teknologi, sadar informasi, berpikir kritis, dan peka terhadap lingkungan. Seorang dikatakan memiliki kemampuan literasi jika ia sudah bisa memahami sesuatu karena membaca informasi yang tepat dan melakukan sesuatu berdasarkan pemahamannya terhadap isi bacaan tersebut. Pemanfaatan internet dalam pembelajaran sastra dinilai dapat dijadikan sebagai salah satu model pembelajaran yang disinyalir bisa menumbuhkan kemandirian dalam pembelajaran Sastra Populer. Untuk mengkaji tentang proses pembelajaran Sastra Populer berbasis Wattpad, penelitian ini menggunakan pendekatan mixed methods. Hasil penelitian menunjukkan bahwa aplikasi Wattpad dapat membantu mahasiswa dalam mengasah keterampilan literasi baca tulis. Penggunaan Wattpad dinilai dapat memberikan pengalaman belajar yang menarik bagi mahasiswa.
\end{abstract}

Kata kunci: manajemen pembelajaran, blended learning, wattpad

\begin{abstract}
Student literacy ability of Indonesian Literature Study Program in Ahmad Dahlan University still lacks attention and handling. This resulted in a low ability of students in literacy literacy skills. While literacy skills can help students to develop critical thinking, divergent thinking, and positive thinking in solving problems. As scholars, prospective scientists and agents of change, students are required to master literacy skills and critical thinking in facing the 21st century's fierce competition. Literacy ability in question here is literacy in the broad sense of being aware of technology, conscious of information, thinking critically, and sensitive to the environment. A person is said to have literacy skills if he is able to understand something because he reads the right information and does something based on his understanding of the contents of the reading. The use of the internet in literary learning is considered to be used as one of the learning models which is supposed to be able to foster independence in learning Popular Literature. To examine the learning process of Wattpad-based Popular Literature, this study uses the mixed methods approach. The results of the study show that the Wattpad application can help students to sharpen literacy skills. The use of Wattpad is considered to provide an interesting learning experience for students.
\end{abstract}

Keywords: learning management, blended learning, wattpad. 


\section{PENDAHULUAN}

Kecerdasan dan pengetahuan suatu bangsa menentukan kualitas bangsa tersebut. Semakin tinggi semangat penduduk suatu bangsa untuk mencari ilmu maka semakin tinggi pula peradabannya. Warga Jepang dalam setahun membaca 10 hingga 15 buku per tahun. Berdasarkan hasil penelitian Perpustakaan Nasional tahun 2017 rata-rata orang Indonesia hanya membaca buku 3-4 kali per minggu, dengan durasi waktu membaca per hari rata-rata 30-59 menit. Sedangkan, jumlah buku yang ditamatkan per tahun rata-rata hanya 5-9 buku (Kompas.com, 26 Maret 2018). Menurut data statistik dari UNESCO, dari 61 negara, Indonesia berada di peringkat 60 dengan tingkat literasi yang dinilai cukup rendah. United Nations Development Programme (UNDP) memaparkan data bahwa tingkat pendidikan berdasarkan Indeks Pembangunan Manusia (IPM) di Indonesia pun masih tergolong rendah, yaitu sekitar 14,6\%. (CNN Indonesia, 10 September 2017). Penyebab rendahnya minat baca ini dikarenakan minimnya kebiasaan membaca sejak dini. Membaca belum dijadikan sebuah kebutuhan dan masih dianggap hanya sebagai hobi. Dalam hal ini peran orang tua dalam mengajarkan kebiasaan membaca menjadi penting untuk meningkatkan kemampuan literasi anak sejak dini. Kondisi minimnya sarana pendidikan dan belum meratanya akses fasilitas pendidikan turut menghambat perkembangan kualitas literasi di Indonesia.

ASEAN Business Outlook Survey 2014 memaparkan data bahwa Indonesia merupakan salah satu negara tujuan investasi asing dan bahkan menjadi salah satu tujuan utama di wilayah ASEAN. Menurut Zubaidah (2016:2) survei tersebut mengindikasikan fakta yang kurang baik, bahwa Indonesia memiliki tenaga kerja dengan tingkat keahlian rendah dan murah. Jika dibandingkan dengan lulusan negara lain yang lebih ahli dan terlatih, seperti di negara Filipina sebagai peringkat tertinggi. Tentu saja Bangsa Indonesia tidak akan mampu bersaing dan akan kehilangan kesempatan kerja yang lebih baik, jika tidak didukung suatu program yang dapat mencetak lulusan dengan kemampuan dan keterampilan yang mumpuni. Bermunculanlah alternatif pekerjaan baru berbasis produksi, analisis, distribusi dan konsumsi informasi. Seiring dengan perubahan pola hidup manusia akibat hadirnya teknologi, tempat kerja menjadi lebih berbasis komputer dan bertransformasi. Dibandingkan dengan pada masa 20 atau 30 tahun yang lalu, para lulusan Indonesia kini membutuhkan keterampilan lebih untuk berhasil dalam menghadapi persaingan ketat abad ke-21. Hal ini merupakan tantangan yang harus disikapi dengan sebaik-baiknya.

Harus diakui bahwa kemampuan literasi mahasiswa Prodi Sastra Indonesia Universitas Ahmad Dahlan masih kurang mendapatkan perhatian dan penanganan. Hal tersebut mengakibatkan rendahnya kemampuan mahasiswa dalam kemampuan literasi. Padahal kemampuan literasi ini dapat membantu mahasiswa untuk mengembangkan berpikir kritis, divergent thinking, dan positive thinking dalam menyelesaikan masalah. Sebagai insan cendekia, calon ilmuwan dan agen perubahan, mahasiswa dituntut untuk menguasai kemampuan literasi serta berfikir kritis dalam menghadapi persaingan ketat abad ke-21.

Kemampuan literasi yang dimaksud adalah keberaksaraan atau literasi dalam arti luas yaitu sadar akan teknologi, sadar informasi, berpikir kritis, dan peka terhadap lingkungan. Seorang dikatakan memiliki kemampuan literasi jika ia sudah bisa memahami sesuatu karena membaca informasi yang tepat dan melakukan sesuatu berdasarkan pemahamannya terhadap isi bacaan tersebut. Untuk memahami ide dan gagasan secara luas (divergent thinking) dalam sebuah teks sastra diperlukan aktifitas membaca, karena dengan membaca seseorang akan mengalami proses berpikir. Menurut Sayuti (2007) "aktifitas menulis apapun, jodohnya adalah membaca".

Hasil dari kegiatan membaca mahasiswa akan mendapatkan wawasan dan gagasan yang 
luas, sehingga dapat meningkatkan kemampuan menulis. Keterampilan berpikir kritis merupakan keterampilan yang dibutuhkan dalam menghadapi persaingan ketat abad ke-21. Keterampilan berpikir kritis ini meliputi kemampuan mengakses, menganalisis, mensintesis informasi yang dapat dibelajarkan, dilatihkan dan dikuasai (P21, 2007a; Redecker et al 2011). Mahasiswa pada umumnya kesulitan untuk berpikir secara multiple perspective, divergent thinking, dan positive thingking dalam menyelesaikan masalah. Padahal kemampuan berpikir kritis akan menjadikan dirinya sebagai manusia yang cerdas dalam berpikir, bijaksana dan kritis dalam menyelesaikan masalah.

Liliani (2012) mengurai tentang permasalahan yang dihadapi siswa dalam pembelajaran Sastra, salah satunya adalah pembelajaran membaca dan menulis sastra, menginterpretasikan karya sastra dan berunjuk peran. Beberapa penyebab di antaranya adalah karena jumlah jam pelajaran yang disediakan, atmosfir pembelajaran sastra yang masih rendah, minimnya keterampilan mengajar mata pelajaran kesusastraan, serta kurang beraninya melakukan terobosan dengan kemajuan teknologi (Liliani, 2012 : 84). Rusman (2011) menyitir apa yang dikemukakan Keller bahwa metode pembelajaran konvensional dianggap kurang menarik. Guru bukanlah satu-satunya pemegang otoritas pengetahuan di kelas. Siswa harus diberi kemandirian untuk belajar dengan memanfaatkan berbagai sumber belajar (Rusman, 2011 : 132).

Pemanfaatan internet dalam pembelajaran sastra dijadikan sebagai salah satu model pembelajaran yang disinyalir bisa menumbuhkan kemandirian belajar sastra. Berbagai aplikasi internet sudah tersedia untuk dimanfaatkan secara optimal oleh pengajar sebagai sarana penyampaian materi pembelajaran khususnya pembelajaran sastra. Salah satu aplikasi yang digunakan dalam pembelajaran sastra populer di Prodi Sastra Indonesia Universitas Ahmad Dahlan adalah penggunaan aplikasi Wattpad. Penelitian ini bertujuan untuk mengkaji proses pembelajaran Sastra Populer yang berbasis Wattpad sebagai upaya peningkatan kemampuan literasi baca tulis, pada mahasiswa Sastra Indonesia Universitas Ahmad Dahlan.

\section{METODE}

Penelitian ini merupakan penelitian Mixed Methods yaitu penelitian yang menggabungkan dua bentuk pendekatan dalam sebuah penelitian, yaitu kualitatif dan kuantitatif (Creswell, 2010: 5). Sugiyono (2011:18) berpendapat bahwa mix methods adalah metode penelitian yang menggabungkan antara dua metode kualitatif dan kuantitatif dalam sebuah kegiatan penelitian, agar diperoleh data yang lebih komprehensif, valid reliabel dan objektif.

Penelitian ini menggunakan strategi metode campuran bertahap (sequential mixed methods) (Creswell, 2010: 332). Tahap awal dilakukan observasi yang dilengkapi dengan pedoman observasi. Kemudian melakukan wawancara dengan berdasar pada pedoman wawancara, dengan dosen pengampu dan mahasiswa prodi Sastra Indonesia semester 3 untuk mendapatkan data kualitatif tentang pembelajaran Sastra Populer. Selain itu dilakukan analisa dokumen berupa silabus dan Rencana Pembelajaran Semester (RPS) mata kuliah Sastra Populer dan akun Wattpad. Langkah selanjutnya adalah menggunakan pendekatan kuantitatif yaitu dengan teknik survey untuk menganalisa pemanfaatan aplikasi Wattpad pada pembelajaran Sastra Populer. Kuesioner disebarkan kepada mahasiswa Sastra Indonesia Universitas Ahmad Dahlan sebanyak 42 orang.

Adapun data sekunder dalam kajian ini adalah sumber yang berhubungan dengan permasalahan dalam objek tulisan ini. Hampir semua jenis bahan kepustakaan baik buku, artikel ataupun essai dikelompokkan dalam data sekunder. Semua data yang diperoleh dianalisis, untuk kemudian dilakukan 
pengkajian ulang. Agar analisis data yang dihasilkan lebih akurat, maka dilakukan diskusi dan konsultasi dengan Ketua Prodi Sastra Indonesia, dan Dekan Fakultas Sastra, Budaya dan Komunikasi.

\section{PEMBAHASAN}

Perencanaan Pembelajaran Sastra Populer

Sebelum melaksanakan kegiatan pembelajaran Sastra Populer dosen mempersiapkan berbagai hal yang dibutuhkan dalam pelaksanaan pembelajaran. Aspek yang dipersiapkan tersebut meliputi analisis kurikulum, analisis kebutuhan pembelajaran, metode yang akan digunakan, evaluasi dan strategi yang cocok, serta menyiapkan media yang akan digunakan. Untuk analisis kurikulum yang pertama kali dipersiapkan adalah silabus, RPS, dan juga materi yang akan digunakan dalam kegiatan pembelajaran. Silabus merupakan perangkat pembelajaran yang dimanfaatkan sebagai panduan pelaksanaan pembelajaran. Silabus mata kuliah sastra populer memiliki komponenkomponen berupa (1) judul, (2) identitas, (3) deskripsi mata kuliah, (4) tujuan perkuliahan, (5) materi perkuliahan, (6) evaluasi perkuliahan, dan (7) daftar rujukan.

Tujuan perkuliahan sastra populer diarahkan pada (1) penguasaan teori dan aplikasi teori dalam membuat rancangan model pembelajaran sastra populer; (2) materi perkuliahan beberapa poin berisikan teoriteori sastra populer dan pembelajaran serta aplikasi teori dalam pengembangan perencanaan model pembelajaran sastra populer; (3) materi pembelajaran sastra populer diarahkan pada pelatihan kemampuan berpikir kritis; (4) Dalam pembuatan model pembelajaran sastra populer, berbagai jenis teks dijadikan bahan pertimbangannya; (5) pengelolaan kegiatan pembelajaran mempertimbangkan adanya kegiatan kelompok dan individu; (6) evaluasi pembelajaran sastra populer difokuskan pada evaluasi teori dan evaluasi praktik pengembangan model pembelajaran sastra populer; (7) setiap tagihan hasil evaluasi diberi bobot yang berbeda berdasarkan tingkat kesulitan dan keluasan materinya; dan (8) sumber belajar diperoleh dari buku, kurikulum, dan artikel dari berbagai media.

Penggunaan Wattpad sebagai media pembelajaran Sastra Populer digunakan dosen pengampu untuk mengkaji karya sastra populer. Alasan dosen pengampu memilih menggunakan Wattpad adalah berdasarkan kebutuhan dari mahasiswa di kelas Sastra Populer. Berdasarkan angket yang disebarkan kepada mahasiswa kelas Sastra Populer, dapat diketahui bahwa sebanyak kebanyakan mahasiswa lebih senang membaca bacaan yang sifatnya elektronik atau daring di samping membaca buku-buku cetak. Dalam memilih bacaan sebagai sumber bahan ajar, mahasiswa lebih menyukai membaca karya sastra dalam bentuk novel dan cerpen. Novel dan cerpen yang dimaksud adalah novel/cerpen dari jenis sastra populer, sastra religius dan Chick Lit. Jenis karya dari mulai karya sastra populer, karya sastra religius, Chick lit dan Teen lit.

\section{Diagram 1. Pemilihan Genre Sastra}

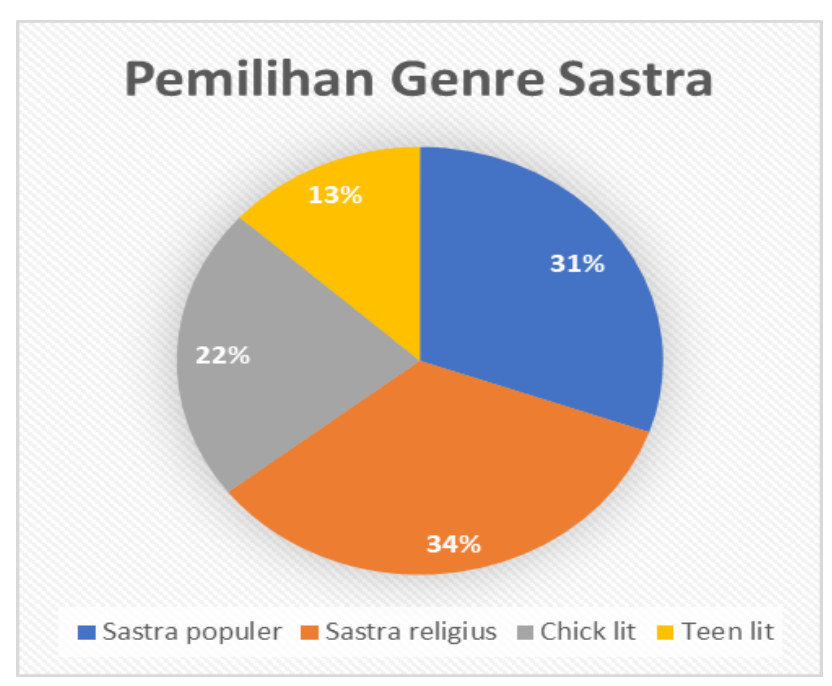




\section{Diagram 2. Pemilihan Jenis Karya Sastra}

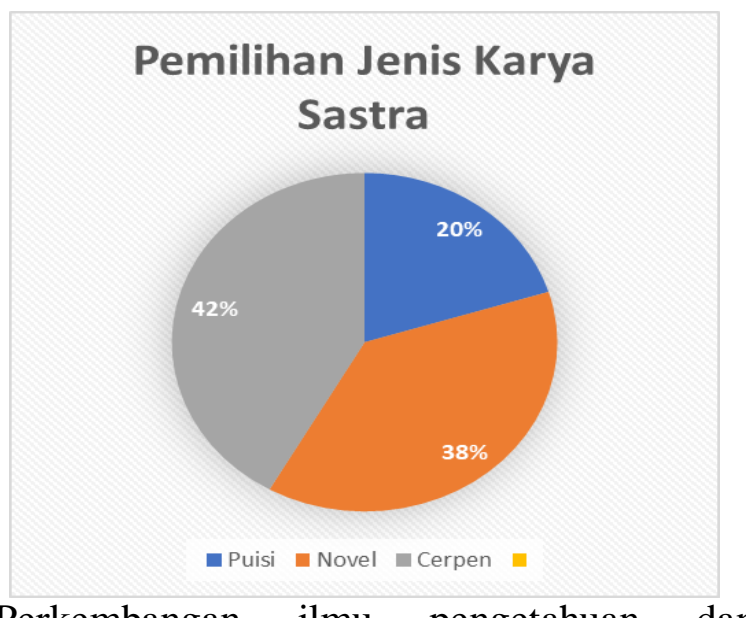

Perkembangan ilmu pengetahuan dan teknologi membawa jejaring sosial sangat populer pada perkembangan komunikasi saat ini. Tidak heran jika generasi muda sangat akrab dengan jejaring sosial di dalam kehidupannya. Demikian pula halnya dengan mahasiswa Sastra Indonesia Universitas Ahmad Dahlan. Hasil angket membuktikan bahwa mereka lebih menyukai membaca karya-karya sastra yang terdapat di jejaring sosial seperti aplikasi Wattpad. Dalam hal ini jejaring sosial mendorong terciptanya sebuah budaya baru yang memungkinkan proses pendidikan dilakukan dalam ruang lain secara daring.

\section{Pelaksanaan Pembelajaran Sastra Populer} Seiring dengan perkembangan teknologi informasi dan komunikasi metode pembelajaran, proses pembelajaran dan media pembelajaran turut mengalami banyak perkembangan. Salah satunya adalah model pembelajaran berbasis internet yang mendorong mahasiswa belajar tidak lagi hanya mendengarkan uraian materi dari dosen tetapi mahasiswa juga melakukan aktivitas lain seperti mengamati, melakukan, mendemonstrasikan dan lain-lain.

Bersandar pada Kurikulum KKNI dan Standar Nasional Dikti tahun 2015 paradigma pendidikan tinggi harus diubah yang pada awalnya pengajaran berpusat pada dosen menjadi pengajaran yang berpusat kepada mahasiswa. Proses pembelajaran yang termaktub pada Standar Nasional Dikti harus memiliki karakteristik yang bersifat interaktif, holistik, integratif, saintifik, kontekstual, tematik, efektif, kolaboratif, dan berpusat pada mahasiswa. Metode pembelajaran sastra dengan memanfaatkan aplikasi Wattpad mencerminkan metode pengajaran menitikberatkan pada student based learning.

E-learning adalah sebuah proses pembelajaran yang menggunakan media teknologi informasi dan komunikasi berupa komputer dan jaringan internet atau intranet. Proses pembelajaran e-learning dapat dilakukan kapan dan dimana saja dengan cara mengakses bahan ajar yang tersedia di jaringan internet. E-learning tidak membutuhkan ruangan (tempat) yang luas sebagaimana ruang kelas konvensional, sehingga dapat memperpendek jarak antara pendidik dan peserta didik. Pembelajaran $e$ learning menurut Bates dan Wulf (1996) seperti yang dikutip Wijaya (2012) dapat meningkatkan interaksi pembelajaran dan mempermudah penyempurnaan dan penyimpanan materi pembelajaran.

Model pembelajaran dengan menggunakan teknologi daring ini memadukan strategi pembelajaran yaitu pembelajaran konvensional dan pembelajaran berbasis daring atau yang lebih dikenal dengan istilah blended learning. Dalam dunia pendidikan tinggi, istilah blended learning merupakan sebuah istilah yang relatif baru. Istilah blended learning merupakan kombinasi pembelajaran antara unsur-unsur pembelajaran tatap muka langsung dan teknologi daring (Heinze \& Procter, 2006). blended learning memberikan keuntungan bagi mahasiswa terkait dengan peningkatan interaksi pembelajaran sekaligus sebagai bentuk dukungan teknologi informasi dan komunikasi ke arah model pembelajaran baru (Graham, 2006). 
Untuk memperoleh pengetahuan yang diinginkannya, teknologi daring mendorong pemakainya melakukan interaksi. Interaksi yang dimaksud adalah kemampuan komputer memberikan umpan balik (feedback) yang segera dapat diakses pemakainya (Faridi, 2009: 60). Teknologi daring memberikan sambungan (konektivitas) dan jangkauan yang sangat luas sehingga akses data dan informasi tidak dibatasi waktu dan tempat. Akses aplikasi daring tidak dibatasi oleh waktu. Pencarian informasi melalui internet dapat dilakukan kapan saja. Akses informasi daring dinilai lebih cepat dibandingkan dengan mencari informasi lewat buku-buku di perpustakaan.

Beberapa hasil penelitian dari Murphy, 2002; Osguthorpe \& Graham, 2003; Riffell \& Sibley, 2003; Voos, 2003; Dziuban et al., 2004, membuktikan bahwa strategi blended learning memiliki manfaat yang beragam, diantaranya tercapainya keberhasilan dalam tujuan pembelajaran, mengubah pola pembelajaran menjadi berpusat pada mahasiswa, dan dapat meningkatkan kemandirian mahasiswa dalam belajar. (Murphy, 2002; Osguthorpe \& Graham, 2003; Riffell \& Sibley, 2003; Voos, 2003; Dziuban et al., 2004). Akan tetapi penggunaan teknologi daring dalam pembelajaran harus mempertimbangan beberapa hal, yaitu ketersediaan jaringan, software (peranti lunak) yang tidak mahal, efek terhadap kurikulum yang ada skill dan knowledge, dan attitude terhadap internet. Model pembelajaran berbasis e-learning merupakan model pembelajaran yang umumnya digemari mahasiswa. Pemanfaatan media pembelajaran berbasis e-learning memiliki potensi membuat mahasiswa mampu mengelaborasikan kepribadian (Angkowo, 2007: 10-11).

Rusman (2012) menjelaskan bahwa pembelajaran berbasis web merupakan suatu kegiatan pembelajaran yang memanfaatkan media situs (website) yang bisa diakses melalui jaringan internet (Rusman, 2012:291). Mengacu pada konsep yang dikemukakan Rusman tersebut pemanfaatan aplikasi Wattpad sebagai salah media pembelajaran sastra termasuk salah satu jenis penerapan dari pembelajaran elektronik (e-learning).

\section{Pemanfaatan Wattpad sebagai media pembelajaran Sastra Populer.}

Wattpad adalah aplikasi yang memungkinkan penggunanya untuk membaca ataupun mengirimkan karya sastra dalam bentuk artikel, cerita pendek, novel dan lain-lain. Wattpad merupakan situs web yang memungkinkan orang menemukan cerita dari para pengguna yang mencakup berbagai genre. Wattpad juga dijadikan sebagai komunitas bagi para pembaca dan penulis. Di balik kesuksesan Wattpad, nama Ivan Yuen dan Allen Lau dikenal sebagai pendiri dari layanan tersebut yang diluncurkan pada tahun 2006.

Beberapa tahun pertama, Allen dan Ivan berjuang mendapatkan pengguna karena teknologi yang diluncurkan masih terlalu dini. Tahun 2007 iphone dan Kindle telah diluncurkan dan membuka kesempatan orang lebih mudah untuk menggunakan aplikasi Wattpad. Seorang penulis Kanada dan advokat untuk literasi, Margaret Atwood yang menjadi kontributor Wattpad mengatakan bahwa aplikasi Wattpad adalah sarana yang sempurna untuk kaum muda dalam proses menulis kreatif. Sejalan dengan tujuan Lau dan Yuen bahwa mereka ingin menyebarkan gagasan tulis kepada miliaran orang dan mempublikasikan karya sastra serta menerima umpan balik dari pembaca secara langsung.

Pada awalnya pengguna komunitas online gratis Wattpad ini berasal dari Amerika Serikat, Britania Raya, Kanada, Filipina, Australia, Rusia, Uni Emirat Arab, dan negara lainnya. (publishersweekly.com, 2012). Kini aplikasi Wattpad sudah memiliki 15 juta pengguna setiap bulannya, dan Ivan berharap jumlahnya akan mencapai 100 sampai 500 
juta pengguna. Ivan dan Allen ditunjuk oleh Financial Times sebagai satu dari tujuh bintang Kanada yang meraih kesuksesan luar biasa dengan Wattpad (Okezone.com, 2018).

Gambar 1: Aplikasi Wattpad

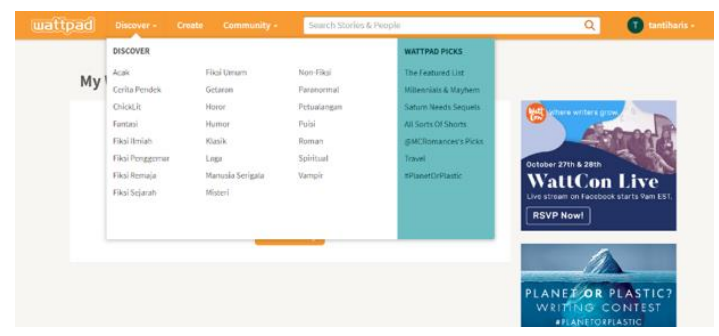

Berdasarkan hasil wawancara dengan dosen pengampu aplikasi Wattpad membantu dosen dalam berkomunikasi secara leluasa kepada mahasiswa dan mahasiswa dapat ikut terlibat dalam diskusi dan kerja sama. Aplikasi Wattpad memiliki potensi untuk mendukung pembelajaran dengan cara yang tidak dibatasi oleh waktu dan tempat (Contreras-Castillo et al 2006; Hrastinski 2006). Selain itu dengan menggunakan fitur chat pada aplikasi Wattpad, mahasiswa dimungkinkan untuk berkomunikasi dengan orang lain yang terlibat dalam proses pengkajian karya sastra populer.

Pada aplikasi Wattpad mahasiswa dapat berinteraksi dengan hasil karya sastra yang diunggah oleh temannya, orang lain atau bahkan oleh dosen sebagai materi pengajaran Sastra populer. Mahasiswa dapat melakukan kritik sastra setelah membaca sebuah karya sastra. Dengan demikian baik dosen maupun mahasiswa akan mampu mengembangkan kemampuan teknis dalam mengkaji karya sastra dan mengembangkan kemampuan sosial mereka dalam menghadapi era digital saat ini. Aplikasi Wattpad dengan berbagai kelebihannya juga berpeluang untuk membuka ruang bersosialisasi seseorang dengan orang lain dalam hal literasi baca tulis.

Dapat dikatakan bahwa dengan mengeksplorasi berbagai karya sastra yang terunggah dalam aplikasi Wattpad terunggah dalam aplikasi Wattpad mahasiswa dapat membangun dan menciptakan pengetahuan tentang sastra populer secara mandiri. Mahasiswa dapat berkolaborasi dengan mahasiswa lain dalam membangun pengetahuannya dan memecahkan masalah secara bersama-sama (social constructivism). Aplikasi Wattpad pun dapat turut membentuk suatu komunitas pembelajar (community of learners) yang inklusif, sehingga dengan keterlibatan mahasiswa dalam mengeksplorasi karya sastra yang terunggah di aplikasi Wattpad, diharapkan dapat membangkitkan sikap interaktivitas, kemandirian, aksesibilitas, dan pengayaan (Ditjen GTK 2016:6)

Dalam aplikasi Wattpad tersedia jutaan karya sastra dengan berbagai bahasa. Karya sastra yang terdapat dalam aplikasi Wattpad adalah puisi, novel, cerpen, dan cerbung dalam berbagai genre sastra. Dari mulai sastra populer, sastra religius, Chick Lit, hingga Teen Lit. Karya sastra tersebut ditulis oleh berbagai orang dengan berbagai latar belakang. Semua orang boleh mengunggah tulisannya tanpa ada batasan persyaratan tertentu. Memang pada akhirnya ada beberapa karya sastra yang hanya bisa dikonsumsi oleh orang dewasa. Dalam hal ini kebijakan dari pembaca atau penikmat karya sastra sangat diperlukan. Meskipun Wattpad termasuk salah satu jejaring sosial, pengguna harus bertanggung jawab terhadap karya yang ditulis dan tidak diizinkan untuk melakukan plagiarisme.

Layaknya sebuah karya sastra populer, karya-karya sastra yang terunggah dalam aplikasi Wattpad adalah karya sastra yang lebih mengejar selera pembaca komersial. Kategori sastra ini tidak akan menceritakan sesuatu yang bersifat serius. Hal ini dikarenakan akan mengurangi jumlah penggemarnya. Karya sastra populer lebih mudah dibaca dan lebih mudah dinikmati. Karya sastra tersebut tidak berpretensi mengejar efek estetis, melainkan memberikan hiburan. Isi dari karya sastra popular 
tergolong ringan, tetapi masih aktual dan menarik.

Aplikasi Wattpad selain menyediakan fitur untuk menulis karya sastra, juga menyediakan berbagai fitur-fitur yang berguna bagi pembaca seperti vote (untuk memilih buku), comment (untuk berkomentar tentang buku yang disajikan), share (untuk berbagi), library (untuk menyimpan buku agar dapat dibaca secara offline), follow (untuk mengikuti salah satu member sosial media), dedicate (untuk mendedikasikan pengguna lain), dan masih banyak fitur lainnya. Bagi mahasiswa yang menempuh mata kuliah Sastra Populer, berbagai fitur tersebut berguna untuk mengasah mahasiswa dalam kemampuan literasi baca tulis. Pada fitur vote, mahasiswa dapat membaca dan mengkaji karya sastra yang dikehendaki. Mahasiswa dapat dengan leluasa memilih karya sastra dalam berbagai bahasa dan genre sastra.

Selesai membaca karya sastra yang dipilih, mahasiswa dapat meninggalkan komentar di dalam fitur comment. Komentar yang diberikan pun tidak memiliki batasan jumlah kata, sehingga pembaca dapat dengan leluasa memberikan komentar atau pun kritik terhadap tulisan yang dibacanya. Komentar yang disampaikan biasanya lebih kepada kritikan jalan cerita yang dipaparkan penulis. Tidak sedikit juga yang mengomentari tentang gaya bahasa yang disajikan. Berdasarkan hasil angket yang disebar, sebanyak $82 \%$ mahasiswa selalu membuat ulasan atau komentar setelah membaca karya sastra di Wattpad. Pemaparan komentar ini dapat dianggap sebagai langkah awal mahasiswa dalam melakukan kritik sastra. Oleh karena itu dapat disimpulkan aktifitas membaca di fitur vote dan menulis di fitur comment ini dapat mengasah kemampuan literasi baca tulis dari mahasiswa.

Di dalam aplikasi Wattpad, dosen juga dapat melihat perkembangan literasi baca tulis mahasiswa secara individual melalui akun
Wattpad masing-masing. Untuk aktifitas membaca, dosen dapat mengamatinya pada fitur vote, dan library untuk melihat seberapa banyak karya sastra yang dibaca dan disimpan secara offline. Sementara untuk aktifitas menulis, dosen dapat mencermati fitur share di setiap akun Wattpad mahasiswa. Aplikasi Wattpad mengarahkan mahasiswa untuk mengasah keterampilan literasi baca tulis dengan penggunaan teknologi dalam pembelajaran. Penggunaan Wattpad memberikan pengalaman belajar yang menarik bagi mahasiswa. Menurut hasil angket, mayoritas mahasiswa merasakan manfaat dari penggunaan aplikasi Wattpad bagi pembelajaran sastra populer.

\section{Diagram 3. Grafik Pemanfaatan Wattpad}

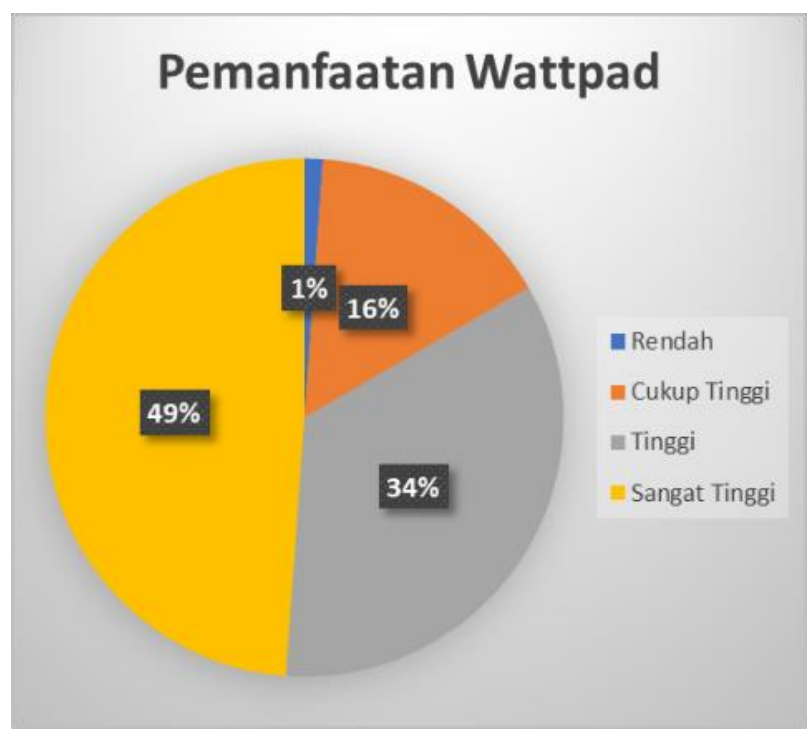

\section{Penilaian Pembelajaran Sastra Populer Berbasis Wattpad}

Tahap akhir dalam proses pembelajaran adalah proses evaluasi pembelajaran. Tujuan diadakannya evaluasi pembelajaran ini adalah untuk mengukur kemampuan mahasiswa dalam manyerap materi yang diajarkan. Evaluasi yang dilakukan hendaknya sejalan dengan tujuan pembelajaran Sastra Populer yang dirumuskan. Berdasarkan hasil wawancara dengan dosen pengampu, 
penilaian hasil belajar mahasiswa dilakukan berdasarkan penugasan individual atau berkelompok, ujian tengah semester, ujian akhir semester, penilaian-diri (selfassessment), penilaian-sejawat (peerassessment), dan observasi kinerja mahasiswa melalui tampilan lisan atau tertulis.

Dosen pengampu menggunakan kriteria penilaian dan pembobotannya sesuai dengan Pedoman Evaluasi Akademik yang berlaku pada Universitas Ahmad Dahlan. Sistem penilaian telah dijelaskan kepada mahasiswa ketika awal perkuliahan dimulai. Sementara evaluasi pembelajaran Sastra Populer dilaksanakan dalam bentuk ujian tertulis, lisan, dan penilaian tugas. Evaluasi ini menggunakan jenis soal essay, dan penulisan makalah. Sementara bobot nilai evaluasi pembelajaran sastra populer adalah Ujian Tengah Semester sekitar : 30\%, UAS sekitar : 40\%, dan tugas sekitar : 30\%. Dosen pengampu Sastra Populer dapat mengembangkan sendiri jenis-jenis evaluasi sesuai dengan prinsip pembelajaran yang berbasis Wattpad.

\section{PENUTUP}

Pembelajaran sastra populer berbasis Wattpad ini terdiri atas perencanaan pembelajaran,

\section{DAFTAR PUSTAKA}

Angkowo, R dan Kosasih, R. (2007). Optimalisasi Media Pembelajaran. Jakarta: Grasindo

Bonk, C. J. \& Graham, C. R. (Eds.). (in press). Handbook of blended learning: Global Perspectives, local designs. San Francisco, CA: Pfeiffer Publishing.

Creswell, J. W. (2010). Research Design: Pendekatan Kualitatif, Kuantitatif, dan Mixed. Yogyakarta: Pustaka Pelajar.

Ditjen GTK Kemendikbud. (2016). Buku Pengangan Pelatihan Instruktur pelaksanaan pembelajaran, dan penilaian pembelajaran. Wattpad sebagai media pembelajaran Sastra Populer digunakan sebagai media pembelajaran khususnya dalam pengkajian karya sastra populer. Alasan dosen pengampu memilih menggunakan Wattpad adalah berdasarkan kebutuhan dari mahasiswa di kelas Sastra Populer.

Dengan Wattpad mahasiswa dapat mengeksplorasi berbagai karya sastra yang terunggah dan dapat membangun serta menciptakan pengetahuan tentang sastra populer secara mandiri. Selain itu, mahasiswa dapat berkolaborasi dengan mahasiswa lain dalam membangun pengetahuannya dan memecahkan masalah secara bersama-sama (social constructivism). Aplikasi Wattpad pun dapat turut membentuk suatu komunitas pembelajar (community of learners) yang inklusif, sehingga dengan keterlibatan mahasiswa dalam mengeksplorasi karya sastra yang terunggah di aplikasi Wattpad, diharapkan dapat membangkitkan sikap interaktivitas, kemandirian, aksesibilitas, dan pengayaan. Aplikasi Wattpad mengarahkan mahasiswa untuk mengasah keterampilan literasi baca tulis dengan penggunaan tekonologi dalam pembelajaran. Penggunaan Wattpad memberikan pengalaman belajar yang menarik bagi mahasiswa.

Nasional/Mentor Guru Pembelajar. Jakarta: Kemdikbud.

Faridi, Abdurrachman. (2009). Inovasi Pembelajaran Sastra Berbasis ICT Dalam Rangka Meningkatkan Mutu Pendidikan. Semarang: UNNES.

Graham C.R. (2006). "Blended Learning Systems: Definition, Current Trends, and Future Directions". Dalam C. Bonk \& C. Graham (Eds.), The Handbook of Blended Learning: Global Perspectives, Local Designs. San Francisco: Pfeiffer, hlm. 3 - 21. 
Heinze, A., Procter, C \& Scott, B. (2007). "Use of Conversation Theory to underpin Blended Learning." International Journal of Teaching and Case Studies, 1(1), 108-120.

Kasmadi \& Surianah, Nia. (2013). Panduan Modern Penelitian Kuantitatif. Bandung: Alfabeta.

Liliani, Else. (2012).’Mengurai permasalahan pembelajaran sastra" Prosiding Pengembangan profesionalisme guru bahasa dan Sastra Indonesia, Jakarta : FBS UNY.

Redecker, C., Ala-Mutka, K., Leis, M., Leendertse, M., Punie, Y., Gijsbers, G., Kirschner, P., Stoyanov, S. and Hoogveld, B. (2011). The Future of Learning: Preparing for Change. Luxembourg: Publications Office of the European Union.

Rusman. (2012). Model-Model Pembelajaran. Jakarta: Grasindo.

Sugiyono. (2013). Metode Penelitian Kuantitatif, Kualitatif dan R\&D. bandung: Alfabeta.

Wijaya, Muksin. (2012). "Pengembangan Model Pembelajaran e-Learning Berbasis Web dengan Prinsip ePedagogy dalam Meningkatkan Hasil Belajar" dalam Jurnal Pendidikan Penabur - No.19/Tahun ke11/Desember 2012

Zubaidah, Siti. (2016). Keterampilan Abad Ke-21: Keterampilan Yang Diajarkan Melalui Pembelajaran. Dalam Seminar Nasional Pendidikan dengan tema "Isuisu Strategis Pembelajaran MIPA Abad 21 (hal 2-17). Sintang, Kalimantan Barat: Program Studi Pendidikan Biologi STKIP Persada Khatulistiwa.

https://www.publishersweekly.com/pw/bytopic/authors/pw-select/article/55231pw-select-december-2012-Wattpad- revolutionizes-online-storytelling.html. Diakses tanggal 28 Nopember 2018

Okezone.com. (2018) "Perjalanan Pendiri wattpad yang sukses hingga memiliki 15 juta pengguna"https://techno.okezone.com/r ead/2018/02/11/207/1857963/ perjalanan-pendiri-Wattpad-yangsukses-hingga-miliki-15-juta-pengguna Diakses tanggal 5 Desember 2018.

Kompas.com. (2018) "Jumlah Terbitan Buku di Indonesia Rendah" https://edukasi.kompas.com/read/2012/ 06/25/08121853/Jumlah.Terbitan.Buku di.Indonesia.Rendah. Diakses tanggal 5 Desember 2018.

Cnnindonesia.com. (2018) "Mengapa literasi di Indonesia Sangat Terendah?" https://student.cnnindonesia.com/eduka si/20170910122629-445-

240706/mengapa-literasi-di-indonesiasangat-terendah/. Diakses tanggal 5Desember 2018.

Kompas.com. (2018) "Jumlah Terbitan Buku di Indonesia Rendah" https://nasional.kompas.com/read/2018 /03/26/14432641/per-hari-rata-rataorang-indonesia-hanya-baca-bukukurang-dari-sejam https://Kompas.com Diakses tanggal 5 Desember 2018. 